\title{
POSTHARVEST APPLICATION OF DEFENCE ELICITORS TO MANAGAE ANTHRACNOSE IN MANGO FRUIT
}

\section{K.O.L.C. Karunanayake}

\section{Department of Botany, Faculty of Natural Sciences, The Open University of Sri}

\section{Lanka, Nawala.}

Received: 01 ${ }^{\text {st }}$ September 2018 / Accepted: $29^{\text {th }}$ October 2018

\begin{abstract}
The use of defense elicitors; which are agents that stimulate or trigger disease resistance responses in plants have proved to be attractive alternatives to hazardous chemical fungicides in recent years. The present study investigated the possibility of using Salicylic acid and Bion ${ }^{\circledR}$ as postharvest elicitors on mango fruit. Three local mango cultivars were used in the study, 'Karuthacolomban', 'Rata' and 'Willard'. Salicylic acid was applied as a postharvest spray at concentrations, 100,500 or $1000 \mathrm{mg} / \mathrm{L}$ and Bion® (Acibenzolar-smethyl, 500 WG, SYNGENTA) at 25, 50, 100 and $200 \mathrm{mg} / \mathrm{L}$. Disease development following artificial inoculation (10 ${ }^{5}$ conidia / ml suspension) was assessed. Both elicitors were effective $(\mathrm{P}<0.05)$ in controlling postharvest anthracnose. The most effective concentration of SA was $500 \mathrm{mg} / \mathrm{L}$ for 'Rata', $100 \mathrm{mg} / \mathrm{L}$ for 'Willard' and both 100 and $500 \mathrm{mg} / \mathrm{L}$ for 'Karuthacolomban'. In Bion® the most effective concentration was 50 ppm for 'Rata' and 'Willard' and $25 \mathrm{ppm}$ for 'Karuthacolomban'. In SA treated fruits the percentage reduction in anthracnose ranged
\end{abstract}

\footnotetext{
*Corresponding author Email: kokar@ou.ac.lk;

(D) https://orcid.org/0000-0003-0657-9888

DOI: http:://doi.org/10.4038/josuk.v12i0.8018
(c) (i) This is an open access article distributed under the terms of the Creative Commons Attribution 4.0 International License, which permits unrestricted use, distribution and reproduction in any medium provided the original work is properly credited.


from $40-77 \%$ while values ranged from $67-99 \%$ for Bion ${ }^{\circledR}$ treated fruits. Results indicate that both SA and Bion ${ }^{\circledR}$ can be used to control postharvest mango fruit loss due to anthracnose.

Keywords: Mango, Anthracnose, Elicitors, Bion®, Salicylic acid

\section{INTRODUCTION}

Elicitors are defined as agents that stimulate or trigger disease resistance responses in plants. These agents may be physical, chemical, biotic or even genetic (Bell, 1981). Resistance may be induced as local acquired resistance (LAR), systemic acquired resistance (SAR) or induced systemic resistance (ISR) (Terry and Joyce, 2004). Use of elicitors to combat postharvest diseases of mango has been extensively studied. Zainuri et $a l .$, (2001) reported a significant reduction in mango anthracnose when treated with 200 $m g \mathrm{~L}^{-1}$ of salicylic acid. A significant reduction in disease development, both under natural and artificial inoculation conditions, could be obtained by post-harvest dips in 2000 $\mathrm{mg} \mathrm{L}^{-1}$ of salicylic acid. In post-harvest vacuum infiltration, $1000 \mathrm{mg} \mathrm{L}^{-1}$ of salicylic acid (SA) was sufficient to give a significant reduction in anthracnose (Zainuri et al., 2001). The reduction in disease development was attributed to delay in fruit ripening brought about by an anti-ethylene effect of salicylic acid. In Thailand, mango inflorescences were treated with SA at a concentration of $100 \mathrm{mg} \mathrm{L}^{-1}$ which significantly reduced anthracnose disease incidence (Leu, 1998). Postharvest dip treatments in SA increased polyphenol oxidase activity, phenyl alanine lyase activity, $\beta$-1,3-glucanase and chitinase activity in treated fruits of cultivar 'Matisu' (Zeng et al., 2006). The level of hydrogen peroxide and superoxide radicals which can act as secondary messengers to activate plant defence were also enhanced by salicylic acid treatment (Zeng et al., 2006). Zhu et al., (2008) vacuum infiltrated mango fruits of the cultivar 'Tainong' with BTH (benzo-(1,2,3)-thiadiazole-7- 
carbothioic acid S-methyl ester) (analogous to Bion ${ }^{\circledR}$ ) at a concentration of $1.0 \mathrm{mM}$, incubated fruits at $13^{\circ} \mathrm{C}$ and $85-90 \% \mathrm{RH}$ for $72 \mathrm{hr}$ and then, inoculated fruits. Results showed that both disease severity and incidence were significantly reduced in fruits treated with BTH. Peroxidase, polyphenoloxidase, phenylalanine ammonia-lyase, chitinase and $\beta$ 1,3-glucanase activities and total phenolic compound content in the fruits were enhanced by the BTH treatment during the incubation. Zhu et al., (2008) suggested that these responses may be involved in the induced resistance against pathogen infection. In Sri Lanka, Karunanayake et al., (2016) reported that pre-harvest field application of salicylic acid (SA) and Kasil (liquid potassium silicate) reduced postharvest anthracnose severity and incidence in mango cv 'Karuthacolomban'. The present study investigates the effect of postharvest spray treatment with elicitors, SA and Bion ${ }^{\circledR}$ in reducing anthracnose development on three local mango cultivars with varying natural resistance to anthracnose.

\section{METHODOLOGY}

\section{Sample selection}

Healthy, unripe mango (Mangifera indica) fruits of three cultivars at harvesting maturity, showing no visible blemishes, were selected for experiments. Three cultivars used were; 'Karuthacolomban' highly resistant to anthracnose, 'Willard' highy susceptible to anthracnose and 'Rata' moderately resistant to anthracnose (Karunanayake et al., 2014). Fruits used for experiments were obtained from a wholesale market at Kiribathkumbura, which had a regular supply of mango fruits from Dambulla and the fruits were transported to the laboratory within $24 \mathrm{hr}$ of harvest.

Fruits were washed in running tap water, spread out on clean newspapers and allowed to air dry under ambient conditions. 


\section{Isolation and maintenance of the pathogen}

Colletotrichum gloeosporioides was isolated from ripe mango fruits showing characteristic symptoms of anthracnose disease. Segments $\left(1 \mathrm{~cm}^{3}\right)$ were excised from the leading edge of characteristic anthracnose lesions of the fruit. Isolation and culturing of fungi were carried out under aseptic conditions. The excised tissue segments were placed in a sterile Petridish and surface-sterilized in a $1 \%$ solution of sodium hypochlorite $(\mathrm{NaOCl})($ commercial Clorox solution, diluted to 1/5) for one minute, then washed twice in sterile distilled water to remove all traces of $\mathrm{NaOCl}$. The sterilized tissues were then trimmed to expose the causative organism within. Tissues were dried on sterile blotting paper and aseptically transferred to Petridishes containing potato dextrose agar (PDA). Sub-culturing was carried out once the fungal cultures were grown to obtain and maintain pure cultures. Koch's postulates were performed to confirm the pathogenicity of each isolate. Sub-culturing was carried out at 14 day intervals and conidia from 14 day-old pure cultures were used for inoculations.

\section{Elicitor application}

Surface sterilized fruits were sprayed with selected concentrations of elicitor solutions, salicylic acid (sodium salt) or Bion ${ }$, which were prepared approximately half an hour before the application. The concentrations of salicylic acid (sodium salt, SIGMA®) used were, 0 (control), 100, 500 and $1000 \mathrm{mg} / \mathrm{L}(1 \mathrm{mM}=160 \mathrm{mg} / \mathrm{L})$ and the concentrations of Bion ${ }^{\circledR}$ (Acibenzolar-s-methyl, 500 WG, SYNGENTA) used were, 0 (control) 25, 50, 100 and $200 \mathrm{ppm}$. As Bion® (Syngenta) contained only $50 \%$ active ingredients, to prepare $25 \mathrm{ppm}, 2.5 \mathrm{mg}$ Bion ${ }^{\circledR}$ was dissolved in $50 \mathrm{ml}$ of sterile distilled water $(1 \mathrm{ppm}=1 \mathrm{mg} / 1000 \mathrm{ml})$. Each elicitor concentration was prepared to contain $50 \mathrm{ml}$ of solution. Tween 20 (Sigma $\left.{ }^{\circledR}\right)$ was added to each elicitor solution $(10 \mu \mathrm{l}$ per $100 \mathrm{ml}$ solution) to enable good wetting of the fruit. Sterile distilled water with Tween 20 served 
as the control. The prepared solutions were evenly sprayed on to the entire surface area of each fruit, until finely misted, using an atomizer (KNF NEUBERG D-79112 Freiburg). Eight replicate fruits were used per elicitor concentration in one trial and three trials were performed. Sprayed fruits were maintained in moist chambers at $28{ }^{\circ} \mathrm{C}$ and under $100 \%$ relative humidity.

\section{Inoculation of fruits}

After 72 hours of incubation, the fruits were removed from the moist chambers and the inoculated surface of each fruit was wiped with sterile cotton wool moistened with sterile distilled water. This was done to remove elicitor residues remaining on the fruit surface. The fruits were inoculated with a conidial suspension of C. gloeosporioides $\left(10^{5}\right.$ conidia / $\mathrm{mL}$ ). Three, $20 \mu \mathrm{l}$ drops of the conidial suspension was placed along the long axis of each fruit and the position of each drop was outlined using a carbon pen. Inoculated fruits were returned to moist chambers for incubation.

Daily observations were made on salicylic acid treated, Bion ${ }^{\circledR}$ treated and distilled water treated (control) fruits. After the initiation of lesions, the diameter was measured on two axes at right angles to each other at each inoculated spot and the average was obtained. Diseased area was mathematically calculated using the average radius from the diameter measurement. The reduction in lesion area in treated fruits as an average value compared to the lesion area of control was mathematically calculated and a percentage value was calculated. 


\section{Statistical analysis}

Three trials were performed and each trial was considered as a separate block and data pertaining to each day was analyzed for variance using ANOVA in a completely randomized block design with SAS computer software (version 6.12) at the $5 \%$ probability level along with Duncan's MRT to compare the treatments.

\section{The toxicity of elicitors against $C$. gloeosporioides}

The direct fungi-toxicity of the effective concentrations of elicitors selected from the above experiment against $C$. gloeosporioides was determined using a spore germination assay. A double strength solution of the optimum concentration of elicitors were prepared and mixed in a 1:1 ratio with a suspension of conidia of C. gloeosporioides (also prepared at double strength). A 1:1 dilution of the conidial suspension with sterile distilled water was used as the control. Two $20 \mu \mathrm{l}$ drops of the mixture were placed on either side of a clean glass slide. Two slides were prepared for each elicitor and two for the control. The slides were arranged in a slide rack and incubated in a moist chamber. Germination was terminated following 16 hours of incubation by adding a drop of lactophenol mixed with cotton blue. One hundred randomly selected conidia in each drop were counted (from several fields of vision under high power of a light microscope) for germination and the percentage germination was calculated. The experiment was performed twice. 


\section{RESULTS}

\section{Elicitor application}

\section{Salicylic acid}

Different cultivars responded differently to the elicitor treatment. Anthracnose lesions were visible on cultivars 'Rata' and 'Willard' four days after inoculation whereas, lesions on cultivar 'Karuthacolomban'appeared 7 days after inoculation. In all three cultivars, anthracnose lesions were smaller in fruits which received salicylic acid treatments prior to inoculation compared to the control fruits. In cultivar 'Rata' the smallest anthracnose lesions were in the fruits treated with $500 \mathrm{mg} / \mathrm{L}$ salicylic acid and in fruits of cultivar 'Willard' upon inoculation, the smallest lesions were developed on fruits treated with $100 \mathrm{mg} / \mathrm{L} \mathrm{SA}$ (Table 1). In cultivar 'Karuthacolomban' both 100 and 500 $\mathrm{mg} / \mathrm{L}$ SA seemed to be effective. However, fruits treated with either higher or lower concentrations resulted in larger lesions (Table 1).

Statistical analysis showed that fruits treated with $500 \mathrm{mg} / \mathrm{L}$ salicylic acid in cultivar 'Rata' or $100 \mathrm{mg} / \mathrm{L}$ in cultivar 'Willard' developed significantly smaller lesions $(\mathrm{P}<0.05)$ (Table 1). 
Table 1. Mean lesion area $(\mathrm{mm} 2)$ in inoculated fruits treated with varying concentrations of Salicylic acid as a postharvest treatment prior to inoculation.

\begin{tabular}{llrrrrrr}
\hline Treatment & Day4 & Day5 & Day 6 & Day 7 & Day8 & Day 9 & Day 10 \\
\hline \multicolumn{1}{l}{ Cultivar 'Rata' } & & & & & & \\
Control & $8.16^{\mathrm{a}}$ & $13.65^{\mathrm{a}}$ & $17.5^{\mathrm{a}}$ & $38.33^{\mathrm{a}}$ & $70.51^{\mathrm{a}}$ & $136.12^{\mathrm{a}}$ & $187.7^{\mathrm{a}}$ \\
$100 \mathrm{mg} / \mathrm{L}$ & $5.13^{\mathrm{a}}$ & $13.13^{\mathrm{a}}$ & $17.33^{\mathrm{a}}$ & $32.85^{\mathrm{ab}}$ & $70.37^{\mathrm{a}}$ & $115.41^{\mathrm{ab}}$ & $169.26^{\mathrm{a}}$ \\
$500 \mathrm{mg} / \mathrm{L}$ & $4.24^{\mathrm{a}}$ & $9.7^{\mathrm{a}}$ & $9.97^{\mathrm{b}}$ & $17.9^{\mathrm{b}}$ & $38.85^{\mathrm{b}}$ & $82.43^{\mathrm{b}}$ & $99.7^{\mathrm{b}}$ \\
$1000 \mathrm{mg} / \mathrm{L}$ & $5.13^{\mathrm{a}}$ & $11.28^{\mathrm{a}}$ & $13.79^{\mathrm{ab}}$ & $31.94^{\mathrm{ab}}$ & $59.61^{\mathrm{b}}$ & $114.31^{\mathrm{ab}}$ & $155.7^{\mathrm{a}}$
\end{tabular}

Cultivar 'Willard'

$\begin{array}{lllrrr}\text { Control } & 46.57^{\mathrm{a}} & 149.7^{\mathrm{a}} & 284.63^{\mathrm{a}} & 441.2^{\mathrm{a}} & 622.3^{\mathrm{a}} \\ 100 \mathrm{mg} / \mathrm{L} & 16.20^{\mathrm{b}} & 40.29^{\mathrm{b}} & 91.02^{\mathrm{b}} & 172.4^{\mathrm{b}} & 224.0^{\mathrm{b}} \\ 500 \mathrm{mg} / \mathrm{L} & 20.15^{\mathrm{b}} & 70.69^{\mathrm{a}} & 161.42^{\mathrm{a}} & 329.2^{\mathrm{a}} & 407.2^{\mathrm{a}} \\ 1000 \mathrm{mg} / \mathrm{L} & 16.20^{\mathrm{b}} & 33.84^{\mathrm{b}} & 106.44^{\mathrm{b}} & 230.6^{\mathrm{a}} & 323.8^{\mathrm{a}}\end{array}$

Cultivar 'Karuthacolomban'

\begin{tabular}{lllrr} 
Control & $2.9^{\mathrm{a}}$ & $4^{\mathrm{a}}$ & $14.5^{\mathrm{a}}$ & $23.6^{\mathrm{a}}$ \\
$100 \mathrm{mg} / \mathrm{L}$ & $1.6^{\mathrm{a}}$ & $2.5^{\mathrm{a}}$ & $7.5^{\mathrm{a}}$ & $8.9^{\mathrm{b}}$ \\
$500 \mathrm{mg} / \mathrm{L}$ & $0.67^{\mathrm{b}}$ & $2.2^{\mathrm{a}}$ & $10.6^{\mathrm{a}}$ & $13.6^{\mathrm{a}}$ \\
$1000 \mathrm{mg} / \mathrm{L}$ & $1.8^{\mathrm{a}}$ & $4.4^{\mathrm{a}}$ & $8.6^{\mathrm{a}}$ & $12.6^{\mathrm{a}}$ \\
\hline
\end{tabular}

Values followed by the same letter within each column of each cultivar do not differ significantly at the $5 \%$ probability level (Duncan's Multiple Range Test). 


\section{Bion $^{\circledR}$ (Acibenzolar-S-methyl)}

Different cultivars responded differently to the elicitor treatment. Lesions were measured for ten consecutive days following inoculation and measurable lesions developed five days after inoculation in the cultivars 'Rata' and 'Willard' (Figure 1,2). In cultivar 'Karuthacolomban, lesions appeared 7 days after inoculation (Figure 3). The lesions which developed following inoculation in Bion $^{\circledR}$ treated fruits were significantly smaller in size compared to the lesions in control fruits in all three cultivars (Figure 1, 2, 3). The smallest lesions were visible in the fruits treated with $50 \mathrm{ppm}$ Bion ${ }^{\circledR}$ in the cultivars 'Rata' and 'Willard' (Figure 1, 2) and in fruits treated with $25 \mathrm{ppm}$ Bion $^{\circledR}$ in the cultivar ‘Karuthacolomban’ (Figure 3).

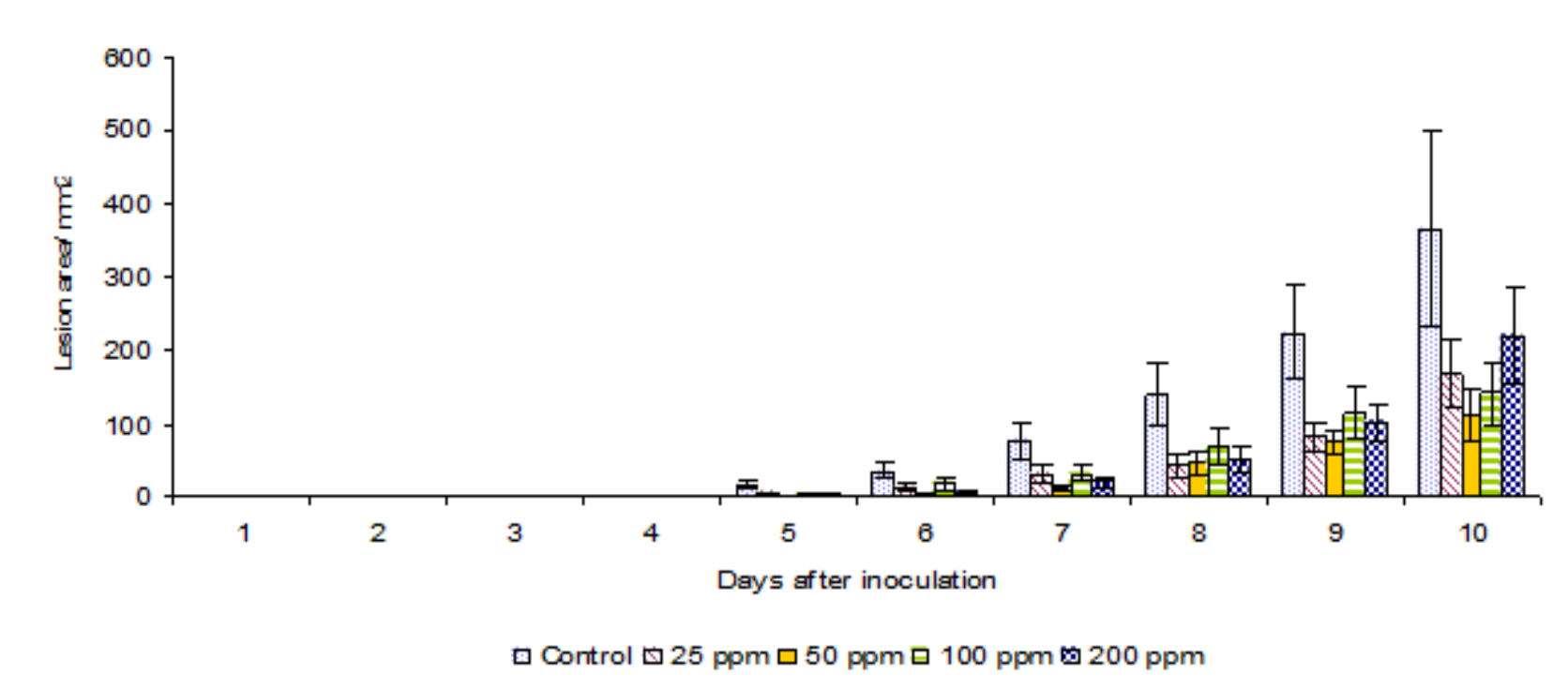

Figure 1: a) Anthracnose lesion development in fruits of cultivar 'Rata' after treatment with Bion $^{\circledR}$ as a postharvest elicitor treatment followed by artificial inoculation. 


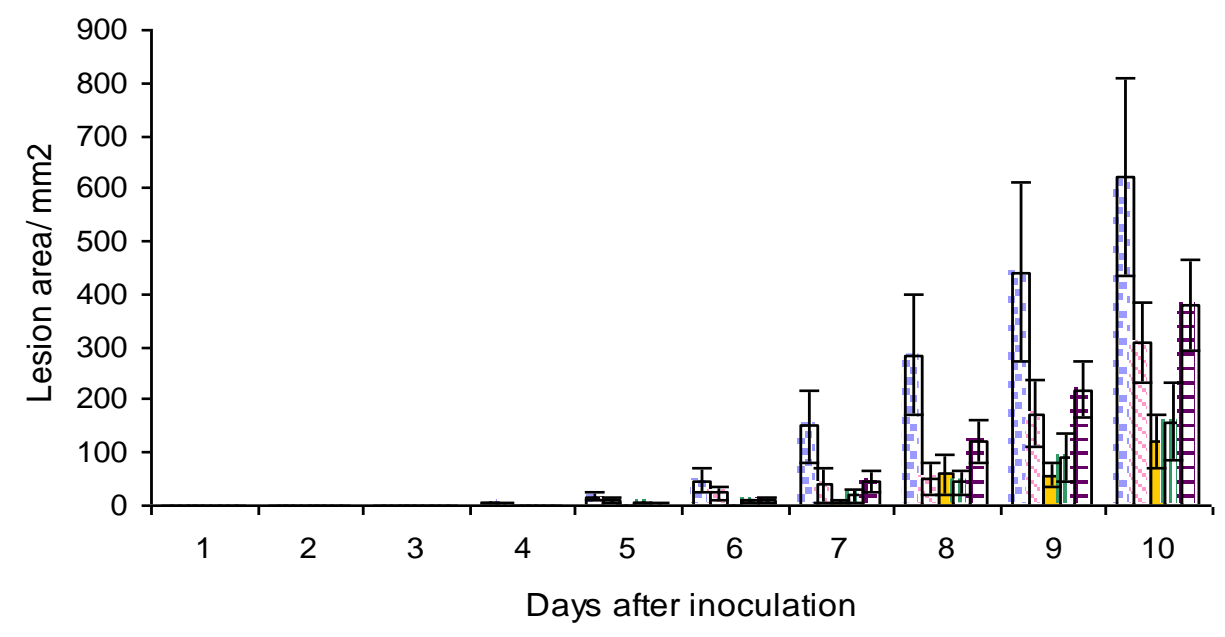

$\square$ Control $\square 25$ ppm $\square 50$ ppm $\square 100$ ppm $\square 200$ ppm

Figure 2: Anthracnose lesion development in fruits of cultivar 'Willard' after treatment with Bion ${ }^{\circledR}$ as a postharvest elicitor treatment followed by artificial inoculation.

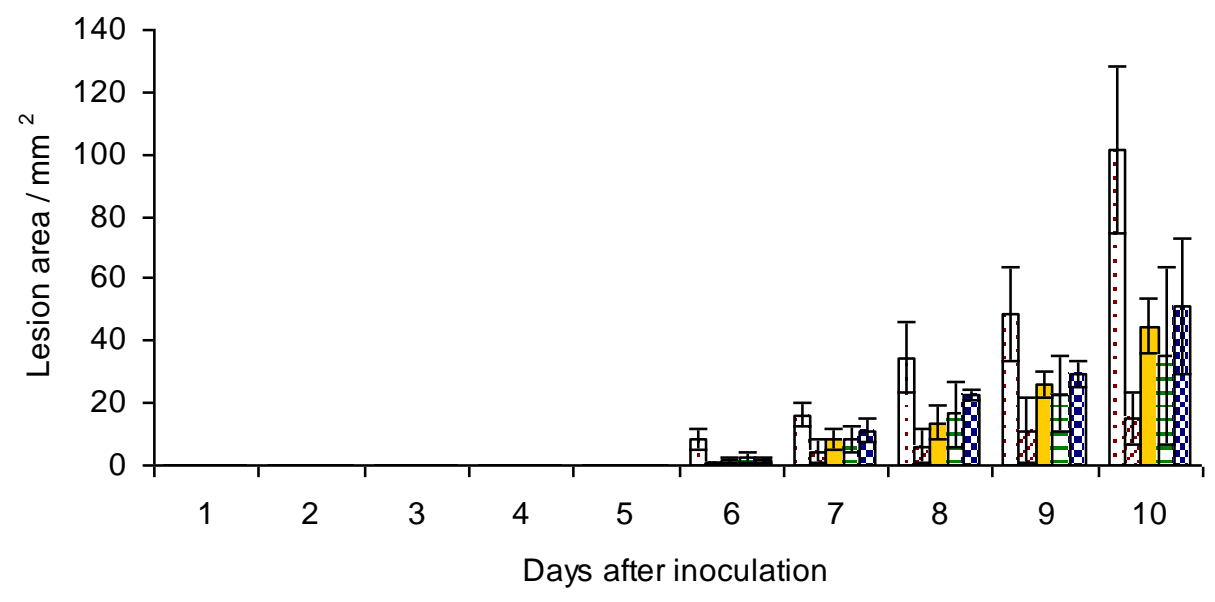

$\square$ Control $\square 25 \mathrm{ppm} \square 50 \mathrm{ppm}$ 曰 $100 \mathrm{ppm}$ ⑳0ppm

Figure 3: Anthracnose lesion development in fruits of cultivar 'Karuthacolomban' after treatment with Bion $^{\circledR}$ as a postharvest elicitor treatment followed by artificial inoculation. 
Treating fruits with $50 \mathrm{ppm}$ Bion $^{\circledR}$ reduced anthracnose development in cultivars 'Rata' and 'Willard' by a large percentage on days five to ten after inoculation. This reduction ranged from 67 to $95 \%$ in cultivar 'Rata' and 80 to $99 \%$ in cultivar 'Willard'. In cultivar 'Karuthacolomban', treating fruits with 25 ppm Bion ${ }^{\circledR}$ reduced anthracnose development by a percentage ranging from 72 to $94 \%$ (Table 2).

A high, significant percentage reduction in lesion area ranging from $67 \%$ to $99 \%$ was achieved by the Bion $^{\circledR}$ treatment. The percentage reduction in anthracnose development in fruits treated with salicylic acid was less than that in fruits treated with Bion ${ }^{\circledR}$. Treating fruits with $500 \mathrm{mg} / \mathrm{l}$ salicylic acid reduced anthracnose development by $40 \%$ on day eight after inoculation and by $53 \%$ on day 6 after inoculation which were the lowest and highest percentage reductions in lesion area (respectively) in the cultivar 'Rata'. Similarly, the percentage reduction in anthracnose development by treating fruits of cultivar 'Willard' with $500 \mathrm{mg} / \mathrm{L}$ salicylic acid ranged from 60 to $73 \%$. Further, treating fruits of cultivar 'Karuthacolomban' with $100 \mathrm{mg} / \mathrm{l}$ salicylic acid reduced anthracnose development by a percentage ranging from 27 to $77 \%$ (Table 2 ). 
Table 2: Average reduction (\%) in lesion area at the optimum elicitor concentration.

Percentage reduction in lesion area (\%)

Treatment

Days after inoculation

5

6

7

8

9

10

Salicylic acid

'Rata' (500 mg/l)

45

$53.3^{*}$

$45^{*}$

$40 *$

46.8*

'Willard' (100 mg/l)

$65.2^{*}$

73.08*

68*

$60.9^{*}$

'Karuthacolomban'

'ND' 'ND'

76.9*

45

26.9

42.3

$(500 \mathrm{mg} / \mathrm{l})$

Bion

'Rata' (50 ppm)

$94.9 *$

88*

84.9*

$66.9 * \quad 67 *$

$69.2 *$

'Willard' (50 ppm)

$99.2^{*}$

98*

95.4*

$79.2^{*}$

87*

80.6*

'Karuthacolomban'

'ND'

'ND'

94.3*

72.4*

81.8*

84.9*

(25 ppm)

'ND', measurable lesions had not developed.

* Denotes significant reduction in lesion area at the $5 \%$ probability level, opposed to the control 


\section{The toxicity of elicitors against $C$.gloeosporioides}

Percentage conidia germination of $C$. gloeosporioides was not significantly different among the treatments at $\mathrm{P}=0.05$. Conidia treated with $\mathrm{SA}, \mathrm{Bion}$ and untreated control reported 22.6, 22.4 and $22.3 \%$ germination respectively, 16 hours after incubation in the moist chamber, indicating no significant reduction of conidia germination by the two elicitors.

\section{DISCUSSION}

Anthracnose development commenced sooner in cultivars 'Rata'and 'Willard' which are more susceptible to anthracnose (Karunanayake et al., 2014), compared to cultivar 'Karuthacolomban', which is more resistant. Further, the anthracnose lesions were also larger in cultivar 'Willard' known to be highly susceptible to anthracnose ( Karunanayake et al., 2014) while leasions were smaller in 'Rata' moderately susceptible to anthracnose and

smallest lesions were seen in cultivar 'Karuthacolomban' which is reported to be highly resistant to anthracnose (Karunanayake et al., 2014 ). These differences in anthracnose development between cultivars are due to innate cultivar effect and not due to elicitor treatments. In the postharvest spray treatments, within each cultivar, all concentrations of the elicitors, salicylic acid and Acibenzolar-S-methyl $\left(\right.$ Bion $\left.^{\circledR}\right)$, reduced anthracnose development compared to the untreated control. Of the two elicitors tested at postharvest stage, Acibenzolar-S-methyl (Bion $\left.{ }^{\circledR}\right)$ was more efficient. The effective concentration of Bion ${ }^{\circledR} ; 25$ or $50 \mathrm{ppm}$ was much lower than the effective concentrations of SA; 100 or $500 \mathrm{mg} / \mathrm{L}$. However, the percentage reduction in lesion area was greater by treatment with Bion ${ }$. The 
optimum concentration of salicylic acid was $500 \mathrm{mg} / \mathrm{L}(500 \mathrm{ppm})$ for cultivar 'Rata' but a lower concentration $(100 \mathrm{mg} / \mathrm{l})$ was needed from salicylic acid to control anthracnose in the more susceptible cultivar 'Willard'. A lower concentration (25 ppm) of Bion ${ }^{\circledR}$ was sufficient to control anthracnose in the more resistant cultivar 'Karuthacolomban'. Wanigasekara et al., (2014) however, reported that in Banana cv. 'Embul' pre-harvest spray treatment with SA at $500 \mathrm{mg} / \mathrm{L}$ was $22 \%$ more effective than $200 \mathrm{mg} / \mathrm{L}$ Bion ${ }^{\circledR}$ in controlling postharvest anthracnose.

In postharvest application, anthracnose severity was reduced to a greater extent in the more anthracnose susceptible cultivar 'Willard' as opposed to the other two cultivars. A similar incidence was reported by Dann et al., (1998), where they could control white mold (Sclerotinia sclerotiorum) disease severity (20 to $60 \%$ ) in soybean with the application of Bion ${ }^{\circledR}$ as a soil drench.

Unlike in a fungicide where the fungus is killed and the most effective in doing so would be the highest concentration, elicitors activate the plant defences to protect against invading pathogens at low concentrations. The most effective dose of the two elicitors salicylic acid and its functional analogue Bion ${ }^{\circledR}$ was not the highest but an optimum. Yu and Zheng (2006) reported that salicylic acid could improve the efficacy of the bio-control agent Cryptococcus laurentii against blue mould disease in apple caused by P. expansum. The most effective concentration was $10 \mu \mathrm{g} \mathrm{ml}^{-1}$ whereas higher or lower concentrations tested were less effective.

The optimum concentration of elicitors used in the present study was not directly toxic to $C$. gloeosporioides, as indicated by the conidia germination assay, although higher doses have been reported to have direct fungitoxic effects. Zainuri et al., (2001) report that 
1000, $2000 \mathrm{mg} / 1$ salicylic acid which effectively controlled mango anthracnose was directly fungitoxic. Similarly, Yu and Zheng (2006) have shown that salicylic acid significantly inhibited the spore germination of $P$. expansum in vitro when its concentration was increased

to $1000 \mu \mathrm{g} \mathrm{ml}^{-1}$. However, during this research, fruits sprayed with high concentrations (1000 $\mathrm{mg} / \mathrm{l}$ ) of salicylic acid showed some necrotic spots on the (lower) surface of the fruit where the run off of the spray solutions accumulated during the three day incubation. High concentrations of salicylic acid are reported to show phytotoxic effects (Lopez and Lucas, 2002). Phytotoxicity (causing injury to a plant) of a compound could be due to a number of reasons, in this case of salicylic acid it is not the chemical itself but the higher doses (overload) that appears to have this effect.

\section{CONCLUSION}

Postharvest spray application of Salicylic acid (sodium salt) and Bion ${ }^{\circledR}$ are significantly effective in controlling anthracnose caused by Colletotrichum gloeosporioides in mango fruit. Of the two Elicitors, Bion ${ }^{\circledR}$ at 25 or $50 \mathrm{ppm}$ is more efficient as an elicitor than SA at 100 or $500 \mathrm{mg} / \mathrm{L}$ in controlling anthracnose in mango fruit.

\section{ACKNOWLEDGEMENT}

The Australian Center for International Agricultural Research is acknowledged for funding this research. 


\section{REFERENCES}

Bell, A. A. (1981). Biochemical mechanisms of disease resistance. Annual Review of Plant Physiology 32, 21-81.

Dann, E., Diers, B., Byrum, J. and Hammerschmidt, R. (1998). Effect of treating soybean with 2, 6 dichloroisonicotinic acid (INA) and benzothiadiazole (BTH) on yields and the level of disease caused by Sclerotinia sclerotiorum in field and green house studies. European Journal of Plant Pathology 104, 271-278.

Karunanayake, L.C., Sinniah, G.D., Adikaram, N.K.B and Abayasekara, C.L (2014). Cultivar difference in antifungal activity and the resistance to postharvest anthracnose and stemend rot in mango (Mangifera indica L). Australasian Plant Pathology 43 (2), 151-159.

Karunanayake, L.C., Sinniah, G.D., Adikaram, N.K.B and Abayasekara, C. L. (2016). Alternatives to synthetic fungicides in controlling postharvest Anthracnose and Stemend rot in Mango. Acta Horticulturae 1144, 453-460.

Liu, J.L., Huang, X. D. Fu , Z. D. and He, S.L. (1998). Induced resistance effect of salicylic acid on anthracnose of mango fruits (Colletotrichum gloesporioides). Journal of Tropical and Subtropical Botany 6, 245-248.

Lopez, A. M. Q. and Lucas, J.A. (2002). Effects of plant defence activators on anthracnose disease of cashew. European Journal of Plant Pathology 108, 409-20.

Medagoda, I. (2006). Presentation: Mango cultivars of Sri Lanka and management of a mango plantation. Field day for mango growers and handlers, Dambulla.

Terry, L.A. and Joyce, D.C. (2004). Elicitors of induced disease resistance in postharvest horticultural crops : A brief review. Postharvest Biology and Technology 32, 1-13. 
Yu, T. and Zheng, X. D. (2006). Salicylic acid enhances biocontrol efficacy of the antagonist Cryptococcus laurentii in apple fruit. Journal of Plant Growth Regulation 25(2), 166174

Wanigasekara, U.W.N.P., Adikaram, N.K.B and Abayasekara, C.L. (2014). Preharvest chemical treatment enhances induced resistance in harvested banana fruit cv. Embul and reduces Anthracnose caused by Colletotrichum musae. Journal of the National Science Foundation of Sri Lanka 42 (2), 101-110.

Zainuri, Joyce, D.C., Wearing, A.H., Coates, L. and Terry, L. (2001). Effects of phosphonate and salicylic acid treatments on anthracnose disease development and ripening of 'Kensington Pride' mango fruit. Australian Journal of Experimental Agriculture 41, 805-813.

Zeng, K.F., Cao, J.K.and Jiang, W. (2006). Enhancing disease resistance in harvested mango (Mangifera indica L. cv. 'Matisu') fruit by salicylic acid. Journal of the Science of the Food and Agriculture 86 (5), 694-698.

Zhu, X., Ca, J., Wang, Q. and Jiang, W. (2008). Postharvest infiltration of BTH reduces infection of mango fruits (Mangifera indica L. cv. Tainong) by Colletotrichum gloeosporioides and enhances resistance inducing compounds. Journal of Phytopathology 156 (2), 68-74. 